\title{
PEMBERIAN TUGAS PRA-PEMBELAJARAN UNTUK MENINGKATKAN KESIAPAN BELAJAR SISWA
}

\author{
I Komang Wisnu Budi Wijaya ${ }^{1}$, Ni Wayan Krisna Windayani² \\ ${ }^{1}$ Institut Hindu Dharma Negeri Denpasar ${ }^{2}$ SMA PGRI 1 Denpasar
}

\author{
A R T I C L E I N F O \\ Article history: \\ Received 2 Februari 2020 \\ Received in revised form \\ 26 Februari 2020 \\ Accepted 28 Maret 2020 \\ Available online 20 April \\ 2020
}

\section{Kata Kunci:}

tugas, pra-pembelajaran,

kesiapan, belajar.

\begin{abstract}
A B S T R A K
Penelitian ini bertujuan untuk: 1) mendeskripsikan efektivitas pemberian tugas pra-pembelajaran untuk meningkatkan kesiapan belajar siswa kelas XI IPA1 SMA Laboratorium Undiksha Singaraja Tahun Pelajaran 2015/2016 dan 2) meningkatkan kesiapan belajar siswa melalui pemberian tugas prapembelajaran di kelas XI IPA1 SMA Laboratorium Undiksha Singaraja Tahun Pelajaran 2015/2016. Penelitian ini tergolong dalam penelitian tindakan kelas (PTK). Penelitian ini terdiri dari dua siklus. Masing-masing siklus terdiri dari empat tahap yaitu (1) perencanaan, (2) pelaksanaan, (3) observasi/evaluasi, dan (4) refleksi. Instrumen penelitian yang digunakan adalah yaitu peneliti itu sendiri dan juga menggunakan lembar observasi kesiapan belajar dan lembar pemberian tugas. Hasil penelitiannya adalah sebagai berikut: 1) Penerapan metode pemberian tugas pra-pembelajaran dapat meningkatkan kesiapan belajar Kimia pada siswa kelas XI IPA1 SMA Laboratorium Undiksha Singaraja. Hal ini dapat dilihat dari nilai tugas siswa dan persentase nilai observasi kesiapan belajar siswa, 2) Penerapan metode pemberian tugas pra-
\end{abstract} pembelajaran dapat meningkatkan aktivitas siswa kelas XI IPA1 SMA Laboratorium Undiksha Singaraja dan 3) Penerapan metode pemberian tugas pra-pembelajaran dapat meningkatkan hasil belajar Kimia pada siswa kelas XI IPA1 SMA Laboratorium Undiksha Singaraja.

\begin{abstract}
This research is aimed to (1) know the effectiveness of giving assignments before the lesson in increasing the readiness of students in learning chemistry at grade XI IPA 1 SMA Lab Undiksha, (2) improve the readiness of students in leaening chemistry by giving assignment before the lesson at grade XI IPA 1 SMA Lab Undiksha. This research is classroom action research. This research is conducted two cycles and each cycle consists of planning, implementing, observing/evaluating and reflecting. The instruments used during the research is the reasearcher itself, learning readiness observation sheet, and assigment sheet. The result of experiment shows that giving assignment before the lesson can improve (1) students readiness in learning chemistry, (2) students participation during the class, and (3) students achievement in learning chemistry at grade XI IPA 1 SMA Lab Undiksha.
\end{abstract}

\section{Pendahuluan}

Pendidikan mempunyai peranan yang sangat penting bagi perkembangan dan perwujudan diri individu, terutama bagi perkembangan bangsa dan negara. Untuk menghadapi era globalisasi, dunia pendidikan dituntut untuk mempersiapkan sumber daya manusia yang kompeten agar mampu bersaing di dunia internasional. Pendidikan merupakan modal utama bagi suatu bangsa dalam upaya meningkatkan kualitas sumber daya manusia yang dimilikinya. Sumber daya manusia yang berkualitas akan mampu mengelola sumber daya alam dan memberi layanan secara efektif dan efisien untuk meningkatkan kesejahteraan masyarakat. Oleh karena itu, hampir semua bangsa berusaha meningkatkan kualitas pendidikan yang dimilikinya, termasuk Indonesia. Mutu pendidikan di Indonesia cenderung masih rendah dibandingkan negara-negara lain. Faktor-faktor penyebab rendahnya mutu pendidikan di Indonesia yakni meliputi faktor eksternal maupun faktor internal. Faktor eksternal meliputi lingkungan belajar, sarana dan prasarana pendukung, guru dan metode mengajar. Sedang faktor internal meliputi

\footnotetext{
${ }^{1}$ Corresponding author.

E-mail : wisnu.budiwijaya240191@gmail.com (I Komang Wisnu Budi Wijaya)
} 
tingkat kecerdasan dan kemampuan awal siswa, kesiapan belajar, motivasi dan minat siswa terhadap suatu pelajaran.

Ilmu kimia adalah salah satu cabang dari IPA (Wijaya, Kirna, \& Suardana, 2012). Ilmu Kimia adalah ilmu yang mempelajari gejala khusus yang terjadi pada zat dan segala sesuatu yang berhubungan dengan zat yaitu komposisi, struktur dan sifat, transformasi, dinamika dan energetika zat. Ilmu Kimia juga mempelajari tentang teori, aturan-aturan, fakta, deskripsi dan peristilahan Kimia (Depdiknas, 2006). Kimia merupakan salah satu mata pelajaran yang memiliki pengaruh yang cukup besar dalam kehidupan sehari-hari. Proses belajar Kimia yang baik akan dapat membuat siswa tertarik mempelajari Kimia serta memahami Kimia itu sendiri. Adanya pemahaman siswa terhadap Kimia akan membuat siswa lebih mudah mengaplikasikannya ke situasi baru. Proses belajar tersebut juga dapat membuat siswa mempermudah menyelesaikan suatu permasalahan Kimia sekolah maupun Kimia dalam kehidupan sehari-hari atau dalam ilmu lainnya, sehingga dapat meningkatkan prestasi belajar siswa khususnya bidang Kimia. Dalam kurikulum yang berlaku saat ini, pelajaran kimia diberikan di jenjang pendidikan SMP dan SMA. Pada jenjang SMP, pelajaran kimia terintegrasi dengan pelajaran biologi dan fisika dalam mata pelajaran IPA, sedangkan pada jenjang SMA, pelajaran kimia berdiri sendiri dan tidak terintegrasi seperti halnya di SMP (Wijaya, 2014).

Upaya peningkatan mutu pendidikan di Indonesia, khususnya peningkatan mutu pendidikan Kimia masih terus diupayakan, karena sangat diyakini bahwa Kimia mempunyai peranan yang sangat penting dalam memahami fenomena alam untuk kewaspadaan hidup. Pada kenyataannya dalam pelaksanaan proses pembelajaran masih banyak kendala yang dialami. Banyaknya kendala dalam proses pembelajaran juga dihadapi oleh SMA Laboratorium Undiksha khususnya di kelas XI IPA.

Berdasarkan hasil obsevasi peneliti di kelas XI IPA1, kendala-kendala yang dimaksud dapat dipaparkan sebagai berikut.

Pertama, proses pembelajaran di kelas masih kurang berpusat pada siswa. Walaupun sudah ada variasi dalam mengajar, namun dominasi guru masih terlihat. Hal ini disebabkan karena siswa belum siap untuk mengikuti kegiatan pembelajaran sehingga sering mengakibatkan guru cenderung menerapkan pembelajaran yang bersifat konvensional yang menekankan pada penyampaian informasi tanpa memberikan kesempatan kepada siswa untuk menemukan sendiri konsep yang dipelajari. Akhirnya, penekanan pada pemahaman konsep siswa cenderung diabaikan. Padahal pemahaman konsep kimia yang baik sangatlah penting karena untuk memahami konsep yang baru diperlukan prasyarat pemahaman konsep sebelumnya, sehingga kurangnya pemahaman siswa terhadap konsep materi yang diajarkan mengakibatkan siswa akan mengalami kesulitan dalam memahami konsep materi berikutnya.

Kedua, partisipasi siswa selama proses pembelajaran berlangsung cenderung bersikap pasif. Pada saat siswa diberikan permasalahan yang terkait dengan materi yang diberikan pada pertemuan sebelumnya terdapat beberapa orang siswa tidak dapat menjawab/menyelesaikannya. Kurangnya kemampuan siswa dalam menyelesaikan permasalahan diakibatkan, siswa hanya menghafal materi yang diberikan dan kurang memahaminya. Kurangnya pemahaman tersebut menyebabkan siswa tidak tahu secara praktis proses penemuan dari suatu informasi yang telah diterima baik dari guru maupun dari hasil membaca buku.

Ketiga, di awal pembelajaran ketika guru akan membuka pembelajaran, masih banyak siswa yang belum mempersiapkan buku pelajaran Kimia karena pikiran mereka belum sepenuhnya ada di kelas. Selain itu beberapa dari siswa bahkan tidak tahu materi yang akan dibahas pada hari tersebut. Hal ini diakibatkan karena kurangnya kesiapan belajar siswa yang mengakibatkan proses pembelajaran menjadi terhambat.

Keempat, selama proses pembelajaran, siswa merasa malu dan takut untuk mengemukakan pendapatnya maupun mengajukan pertanyaan. Hal ini menyebabkan guru kesulitan untuk mengetahui sejauh mana penguasaan siswa terhadap materi yang diberikan dan apakah konsep yang dimiliki siswa sudah benar atau masih menyimpang.

Kelima, siswa menganggap Kimia merupakan pelajaran yang sulit. Anggapan tersebut menyebabkan siswa menjadi malas dan enggan untuk mempelajarinya. Kurangnya kemampuan bernalar siswa yaitu berpikir sistematis, logis, dan kritis dalam mengkomunikasikan gagasan-gagasan atau ide-ide menyebabkan belajar menjadi kurang bermakna. Selain itu, siswa menganggap kimia sebagai pelajaran yang membosankan karena banyak menghafal rumus sehingga menimbulkan rasa jenuh terutama bagi siswa yang memang dari awal kurang menyukai pelajaran Kimia.

Faktor-faktor tersebut diperkuat dengan hasil observasi awal terhadap beberapa siswa saat pembelajaran berlangsung di kelas XI IPA1. Menurut penuturan beberapa siswa, terdapat keengganan siswa untuk bertanya dan menjawab pertanyaan selama pembelajaran karena malu dan takut dianggap bodoh oleh teman lain. Apabila ada hal-hal yang kurang jelas mereka lebih memilih bertanya kepada 
temannya, sehingga peluang siswa tersebut mengalami salah konsep besar karena temannya yang ditanya belum tentu paham sepenuhnya tentang materi yang dijelaskan guru. Beberapa siswa juga mengaku tidak tahu harus bertanya apa, acuh tak acuh terhadap materi pembelajaran, dan beranggapan bahwa pelajaran kimia adalah pelajaran yang sulit dan abstrak.

Berdasarkan kendala-kendala yang dipaparkan di atas, penulis menyimpulkan kendala yang paling krusial dan mendasar pada proses pembelajaran yaitu kurangnya kesiapan siswa dalam mengikuti pembelajaran. Kesiapan belajar yang dimaksud adalah kondisi awal suatu kegiatan belajar yang membuat siswa untuk memberi respon atau jawaban untuk mencapai tujuan pembelajaran tertentu. Seorang siswa tidak dapat lepas dari aktivitas belajar dan untuk menunjang hal tersebut diperlukan kesiapan belajar yang baik. Beberapa faktor yang mempengaruhi kesiapan belajar antara lain (1) kondisi fisik, misalnya tubuh tidak sakit (jauh dari gangguan lesu, mengantuk, dan sebagainya). (2) kondisi psikis siswa, misalnya ada hasrat untuk belajar, dapat berkonsentrasi, dan ada motivasi intrinsik. (3) kebutuhan, misalnya buku pelajaran, catatan pelajaran dan perlengkapan. (4) pengetahuan (kognitif) misalnya membaca buku pelajaran atau mencari informasi terkait dengan materi yang akan dipelajari (Slameto, 2003).

Dalam penelitian ini yang digunakan sebagai dasar indikator kesiapan belajar adalah kondisi kognitif dan kebutuhan siswa (kesiapan materiil). Kondisi kognitif yang dimaksud yaitu pengetahuan awal siswa sebelum proses pembelajaran, sedangkan kebutuhan atau kesiapan materiil seperti sumber belajar yang digunakan siswa. Apabila diawal pembelajaran siswa memiliki kesiapan belajar yang bagus maka siswa akan lebih mudah untuk menyerap materi yang diajarkan karena sudah memiliki pengetahuan awal. Hal demikian akan menimbulkan konflik kognitif di dalam diri siswa sehingga siswa akan berusaha untuk merespon pembelajaran baik itu bertanya maupun menjawab pertanyaan yang diberikan guru maupun temannya.

Agar dapat memberi jawaban yang benar tentunya siswa harus mempunyai pengetahuan dengan cara membaca dan mempelajari materi yang akan diajarkan oleh guru. Dalam mempelajari materi tentunya siswa harus mempunyai sumber belajar seperti buku paket dari sekolah maupun buku diktat lain yang masih relevan digunakan sebagai acuan untuk belajar. Dengan adanya kesiapan belajar, siswa akan termotivasi untuk mengoptimalkan hasil belajarnya, sehingga secara otomatis kendala-kendala lain seperti hasil belajar, pemahaman konsep dan kepercayaan diri siswa pun akan teratasi.

Salah satu cara untuk menumbuhkan kesiapan belajar siswa adalah dengan penggunaan metode atau strategi pembelajaran yang bervariasi. Salah satunya adalah memberikan tugas sebelum pembelajaran. Tugas yang diberikan terkait materi yang akan diajarkan pada pertemuan selanjutnya. Adanya tugas pra-pembelajaran dapat meningkatkan aktifitas siswa dalam proses pembelajaran. Dengan mengerjakan tugas berarti siswa telah memiliki kesiapan untuk belajar karena telah mempelajari materi sebelumnya. Jadi siswa sudah memiliki pengetahuan awal sehingga akan lebih siap dalam mengikuti pembelajaran di kelas (Erna, 2008). Hal ini dikarenakan siswa sebelumnya sudah membaca materi terkait tugas yang diberikan sehingga akan merangsang siswa untuk bertanya di kelas. Strategi pemberian tugas sangat penting dilakukan, karena metode ini dapat merangsang, mengembangkan kreatifitas, kemandirian dan membina tanggung jawab siswa (Roestiyah, 2008).

\section{Metode}

Penelitian ini merupakan penelitian tindakan kelas (PTK). Penelitian tindakan kelas merupakan penelitian yang dilakukan guru sebagai peneliti di kelasnya atau bersama-sama dengan orang lain dengan cara merancang, melaksanakan dan merefleksikan tindakan secara kolaboratif dan partisipatif yang bertujuan untuk meningkatkan atau memperbaiki mutu proses pembelajarannya di kelas melalui suatu tindakan tertentu dalam sebuah siklus (Kunandar, 2016). Penelitian dilakukan di SMA Laboratorium Undiksha.

Subjek penelitian ini adalah siswa kelas XI IPA1 SMA Laboratorium Undiksha Singaraja, yang berjumlah 26 siswa. Adapun objek penelitian ini adalah pemberian tugas pra-pembelajaran. Instrumen penelitian yang digunakan yaitu peneliti itu sendiri dan juga menggunakan lembar observasi kesiapan belajar dan lembar pemberian tugas. Lembar observasi kesiapan belajar terdiri dari tiga indikator yaitu : 1) Usaha siswa untuk memiliki sumber belajar, 2) respon siswa dalam bertanya dan 3) respon siswa dalam menanggapi pertanyaan. Terkait instrument pemberian tugas terdiri dari dua indikator yaitu ; 1) pengumpulan tugas dan 2)pengerjaan tugas.

Prosedur penelitian terdiri dari dua siklus. Masing-masing siklus terdiri dari empat tahap yaitu (1) perencanaan, (2) pelaksanaan, (3) observasi/evaluasi, dan (4) refleksi. Tahapan perencanaan terdiri dari ; 1) mengkaji materi, sumber dan media belajar yaitu materi Laju Reaksi, 2) membuat Rencana Pelaksanaan Pembelajaran (RPP), 3) menyiapan media pembelajaran yang digunakan yaitu media pembelajaran powerpoint dan 4) menyusun instrumen penelitian. Pelaksanaan merupakan tahapan peneliti melaksanakan pembelajaran berdasarkan rencana pelaksanaan pembelajaran yang telah disusun pada 
tahap perencanaan. Rencana pelaksanaan pembelajaran yang dirancang menggunakan metode diskusi kelompok yang disesuaikan dengan kurikulum yang digunakan di SMA Laboratorium Undiksha Singaraja yaitu kurikulum KTSP. Setelah itu dilanjutkan dengan observasi dan evaluasi. Kegiatan observasi dilaksanakan secara kontinu selama kegiatan pembelajaran berlangsung. Observasi dilakukan untuk melihat aktivitas pembelajaran baik yang dilakukan guru (peneliti) maupun siswa. Observasi untuk melihat aktivitas pembelajaran tersebut dilakukan oleh peneliti atau rekan peneliti dengan menggunakan lembar observasi atau dapat juga dilakukan dengan menggunakan alat observasi lainnya. Evaluasi yang dilaksanakan meliputi evaluasi mengenai segala komponen yang mempengaruhi proses pembelajaran seperti langkah-langkah pembelajaran, aktivitas siswa dan guru, hal yang menyebabkan siswa pasif dalam keaktifan belajar siswa. Tahapan terakhir adalah refleksi. Refleksi dilakukan pada setiap akhir siklus. Refleksi dilakukan dengan tujuan untuk mengetahui kekurangan-kekurangan dan kelebihan-kelebihan yang terjadi pada setiap tindakan yang dilakukan. Di samping itu, refleksi ini digunakan sebagai dasar penyempurnaan tindakan selanjutnya, sehingga kelemahan-kelemahan yang ada dapat ditekan semaksimal mungkin dan kelebihan yang ada dapat dipertahankan dan dimaksimalkan. Mengenai teknik pengumpulan data dilakukan dengan cara observasi, penugasan, tes dan dokumentasi.

Analisis data dilakukan dengan metode deskripsi kuantitatif. Metode deskripsi kuantitatif adalah suatu cara pengolahan data yang dilakukan dengan jalan menyusun secara sistematis dalam bentuk angka-angka atau persentase mengenai keadaan suatu objek yang diteliti sehingga diperoleh kesimpulan umum (Agung, 1999). Skor kesiapan belajar siswa untuk tiap Siklus dihitung dengan rumus sebagai berikut:

$$
\text { Skor kesiapan belajar }=\frac{\text { skor keseluruhan yang diperoleh kelompok }}{\text { skor maksimum }} \times 100 \%
$$
berikut:

Skor kesiapan belajar tersebut kemudian disesuaikan dengan pedoman kriteria pada Tabel 1 sebagai

Tabel 1. Pedoman Kriteria Skor Kesiapan Belajar

\begin{tabular}{ll}
\hline Presentase & Kriteria \\
\hline $75 \%-100 \%$ & Sangat Tinggi \\
$50 \%-74,99 \%$ & Tinggi \\
$25 \%-49,99 \%$ & Sedang \\
$0 \%-24,99 \%$ & Rendah \\
\hline (Sugiyono, 2010) &
\end{tabular}

(Sugiyono, 2010)

Mengenai skor akhir tugas siswa dengan rumus sebagai berikut.

$$
\text { Skor }=\frac{\text { skor yang diperoleh }}{\text { skor maksimum }} \times 100
$$

Setelah mendapatkan rata-rata nilai tugas siswa kemudian dikonversikan seperti tabel 2 berikut.

Tabel 2. Konversi Nilai Tugas

\begin{tabular}{ll}
\hline Rentang Nilai & Katagori Nilai \\
\hline $90-100$ & Sangat Baik \\
$80-89$ & Baik \\
$65-79$ & Cukup Baik \\
$55-64$ & Kurang Baik \\
$0-54$ & Sangat Kurang Baik \\
\hline (Nurkancana \& Sunartana, 1992)
\end{tabular}

Selain itu dilakukan pula analisis tes hasil belajar untuk menentukan presentasi peningkatan ketuntasan siswa. Siswa dikatakan tuntas belajar jika nilai tes hasil belajar melampui nilai KKM yaitu 78. Setelah itu dilakukan penentuan persentase ketuntasan belajar siswa di setiap siklusnya dengan rumus berikut :

$$
\text { Persen (\%) ketuntasan : } \frac{\text { jumlah siswa tuntas }}{\text { jumlah siswa }} \times 100 \%
$$

Peningkatan prestasi siswa juga dilihat dari hasil belajar jangka pendeknya yang ditunjukkan dengan kenaikan nilai rata-rata tes pada setiap siklus. Dari data yang diperoleh skor untuk setiap tes, rata-rata nilai siswa dengan menggunakan perhitungan sebagai berikut: 


$$
\begin{gathered}
\overline{\boldsymbol{X}}=\frac{\sum \boldsymbol{f x}}{\boldsymbol{N}} \\
\text { Keterangan : } \\
\mathrm{x}=\text { nilai rata-rata (mean) } \\
\mathrm{fx}=\text { jumlah nilai siswa } \\
\mathrm{N}=\text { jumlah siswa } \\
\text { (Sudjana, 2010) }
\end{gathered}
$$

Setelah mendapatkan rata-rata hasil belajar siswa kemudian dikonversikan seperti tabel 3 berikut.

Tabel 3. Konversi Hasil Belajar

\begin{tabular}{ll}
\hline Rentang Nilai & Katagori Nilai \\
\hline $90-100$ & Sangat Baik \\
$80-89$ & Baik \\
$65-79$ & Cukup Baik \\
$55-64$ & Kurang Baik \\
$0-54$ & Sangat Kurang Baik \\
\hline
\end{tabular}

(Nurkancana \& Sunartana, 1992)

\section{Hasil dan pembahasan}

Penelitian ini terdiri atas 2 Siklus, Siklus I dilaksanakan pada materi pembelajaran KD 3.1 Konsep Laju Reaksi dan Faktor-faktor yang Mempengaruhi Laju Reaksi, dan Siklus II dilaksanakan pada materi pembelajaran KD 3.2 yaitu Teori tumbukan dan Persamaan Laju Reaksi. Sebelum pelaksanaan Siklus I, dilakukan observasi terhadap sistem pembelajaran di kelas yaitu kelas XI IPA1 SMA Laboratorium Undiksha Singaraja yang ditemukan berbagai permasalahan dalam pembelajaran.

\section{Hasil Penelitian Siklus I}

Tindakan pada Siklus I dilakukan dengan beberapa tahap, diantaranya refleksi awal, perancanaan, tindakan, pengamatan hasil tindakan, dan refleksi tindakan. Berdasarkan refleksi awal kesiapan belajar siswa tergolong rendah, maka perencanaan yang dilakukan pada Siklus I adalah (1) merancang RPP sesuai dengan kurikulum yang digunakan di SMA Laboratorium Undiksha, yaitu kurikulum KTSP. RPP yang dirancang menggunakan metode diskusi kelompok, (2) menyiapkan lembar kerja siswa yang memuat permasalahan-permasalahan yang ada di sekitar siswa, adapun lembar kerja siswa (LKS) disajikan pada RPP, (3) menyiapkan media berupa alat dan bahan untuk demonstrasi dan praktikum, (4) menyiapkan lembar observasi kesiapan belajar siswa untuk mengukur kesiapan siswa saat

\begin{tabular}{|c|c|c|c|c|}
\hline \multirow[t]{3}{*}{ Siklus I } & Pertemuan & Nilai Tugas Rata-rata & $\begin{array}{c}\text { Rata-Rata Nilai } \\
\text { Tugas Siklus I }\end{array}$ & Kategori \\
\hline & I & 56,3 & 65,1 & Cukup Baik \\
\hline & II & 74,0 & & \\
\hline
\end{tabular}
pelaksanaan pembelajaran, (5) menyiapkan lembar penilaian tugas pra-pembelajaran yang diberikan kepada siswa berupa rangkuman materi yang akan diberikan pada pertemuan berikutnya.

Pada siklus I, dilakukan penilaian terhadap hasil tugas siswa, kesiapan belajar siswa dan hasil belajar siswa. Hasil penilaian terhadap tugas siswa disajikan pada Tabel 4 sebagai berikut.

Tabel 4. Hasil Penilaian Tugas Siswa

Berdasarkan tabel di atas, dimana rata-rata nilai tugas siswa pada Siklus I ialah sebesar 65,1 termasuk katagori cukup baik. Bila diperhatikan perpertemuan terjadi peningkatan rata-rata nilai tugas siswa dimana pada pertemuan pertama rata-rata nilai tugas siswa sebesar 56,3 , kemudian pertemuan kedua mengalami peningkatan menjadi 74.

Data kesiapan belajar siswa kelas XI IPA1 SMA Laboratorium Undiksha Singaraja diperoleh melalui lembar observasi siswa saat proses pelaksanaan pembelajaran. Hasil analisis observasi kesiapan belajar siswa pada Siklus I disajikan pada Tabel 5 
Tabel 5. Analisis Hasil Observasi Kesiapan Belajar Siswa Pada Siklus I

\begin{tabular}{|c|c|c|c|c|}
\hline Siklus I & Pertemuan & Rata-rata Respon Siswa & $\begin{array}{c}\text { Presentase Total } \\
\text { Siklus I }\end{array}$ & Kategori \\
\hline & $\mathrm{I}$ & 41 & $44,6 \%$ & SEDANG \\
\hline & II & 48 & & \\
\hline
\end{tabular}

Berdasarkan tabel di atas, dimana hasil observasi belajar siswa pada Siklus I persentase yang diperoleh ialah sebesar 44,6\% termasuk katagori sedang. Bila diperhatikan perpertemuan terjadi peningkatan rata-rata nilai observasi kesiapan belajar siswa dimana pada pertemuan pertama rata-rata aktivitas hasil observasi kesiapan siswa sebesar 41\%, kemudian pertemuan kedua terjadi sedikit peningkatan aktivitas hasil observasi kesiapan belajar siswa dalam mengikuti pembelajaran sebesar $48 \%$. Secara keseluruhan hasil observasi kesiapan belajar siswa masih dalam katagori sedang dengan rata-rata persentase sebesar 44,6 \% sehingga Siklus I belum dapat dikatakan berhasil sehingga harus dilanjutkan dengan Siklus II.

Selain data kesiapan belajar siswa kelas XI IPA1 SMA Laboratorium Undiksha Singaraja diperoleh juga data hasil belajar siswa setelah diterapkannya pemberian tugas pra-pembelajaran dalam proses pembelajaran. Hasil belajar siswa SMA Laboratorium Undiksha Singaraja dengan penerapan metode pemberian tugas pra-pembelajaran pada KD 3.1 materi Konsep Laju reaksi dan faktor-faktor yang mempengaruhi laju reaksi pada Siklus I diperoleh data sesuai Tabel 6 berikut.

Tabel 6. Hasil Belajar Siswa Pada Siklus I

\begin{tabular}{llll}
\hline Rentang Nilai & Kategori Nilai & Jumlah siswa & Persentase \\
\hline $90-100$ & Sangat Baik & 0 & $0 \%$ \\
$80-89$ & Baik & 7 & $27 \%$ \\
$65-79$ & Cukup Baik & 14 & $54 \%$ \\
$55-64$ & Kurang Baik & 0 & $0 \%$ \\
$0-54$ & Sangat Kurang Baik & 5 & $19 \%$ \\
\hline
\end{tabular}

Berdasarkan tabel diatas dapat menunjukkan sebaran yang merata pada hasil belajar siswa pada Siklus I, dimana 7 orang siswa mendapat nilai pada rentangan 80 - 89 dikategorikan baik atau sebesar 27 $\%$ dari total keseluruhan siswa yang berjumlah 26 orang, 14 orang siswa mendapat nilai pada rentangan 65 - 79 dikategorikan sedang atau sebesar 54\% dari total keseluruhan siswa yang berjumlah 26 orang, 5 orang siswa mendapat nilai pada rentangan 0 - 54 sangat kurang baik atau sebesar $19 \%$ dari total keseluruhan siswa yang berjumlah 26 orang. Rata-rata hasil belajar siswa pada Siklus I adalah 68,12 dengan dikategorikan cukup baik.

Dilihat dari nilai kriteria ketuntasan minimal yang telah ditetapkan oleh guru mata pelajaran Kimia SMA Laboratorium Undiksha Singaraja untuk kelas XI sebesar 78 dalam skala 100 dapat diketahui berdasarkan hasil belajar siswa pada Siklus I jumlah siswa yang tuntas dan siswa yang belum tuntas dalam pembelajaran Kimia materi Konsep Laju Reaksi. Sebaran frekuensi ketuntasan belajar siswa pada Siklus I dapat dilihat pada tabel 7 berikut.

Tabel 7. Sebaran Frekuensi Ketuntasan Belajar Siswa Pada Siklus I

\begin{tabular}{llll}
\hline Rentang Nilai & Keterangan & Jumlah siswa & Persentase \\
\hline$\geq 78$ & Tuntas & 10 & $38,5 \%$ \\
$\leq 78$ & Belum Tuntas & 16 & $61,5 \%$ \\
\hline
\end{tabular}

Berdasarkan pada tabel 7, jumlah siswa tuntas atau yang hasil belajarnya di atas nilai kriteria ketuntasan minimal (KKM) 78 berjumlah 10 orang dari 26 orang siswa atau 38,5\%. Sedangkan siswa yang belum tuntas atau hasil belajarnya di bawah nilai kriteria ketuntasan minimal (KKM) 78 berjumlah 16 orang dari 26 siswa atau 61,5\%. Dapat dikatakan hasil belajar siswa pada Siklus I masih rendah hal ini dibuktikan dengan besarnya persentase siswa yang belum tuntas dibandingkan dengan presentase siswa yang telah tuntas. 


\section{Hasil Penelitian Siklus II}

Pelaksanaan pada Siklus II tidak jauh berbeda dengan pelaksanaan pada Siklus I, karena pelaksanaan Siklus II merupakan penyempurnaan pelaksanaan Siklus I. Pelaksanaan Siklus II dilakuakan dengan beberapa tahap, diantaranya perancanaan, tindakan, pengamatan hasil tindakan, dan refleksi tindakan. Berdasarkan refleksi Siklus I, maka perencanaan yang dilakukan pada Siklus II adalah (1) merancang RPP sesuai dengan kurikulum yang digunakan di SMA Laboratorium Undiksha, yaitu kurikulum KTSP. RPP yang dirancang menggunakan metode diskusi kelompok, adapun RPP yang disusun terlampir, (2) menyiapkan lembar kerja siswa yang memuat permasalahan-permasalahan yang ada di sekitar siswa, adapun lembar kerja siswa (LKS) disajikan pada RPP, (3) menyiapkan media pembelajaran berupa video dan powerpoint, (4) menyiapkan lembar observasi kesiapan belajar siswa untuk mengukur kesiapan siswa saat pelaksanaan pembelajaran, (5) menyiapkan lembar penilaian tugas pra-pembelajaran yang diberikan kepada siswa berupa rangkuman materi yang akan diberikan pada pertemuan berikutnya, (6) menyiapkan kemampuan penguasaan materi sehingga siswa dapat percaya terhadap penjelasan dan jawaban berbagai pertanyaan siswa sehingga siswa lebih antusias mengikuti pembelejaran serta mampu mengelola kelas dengan baik sehingga hubungan antara siswa dengan guru akan baik dan siswa akan lebih antusias dan guru akan selalu dinanti kedatangannya di kelas.

Pada Siklus II, dilakukan juga observasi terhadap tugas siswa, kesiapan belajar dan hasil belajar siswa seperti pada siklus I. Hasil observasi terhadap tugas siswa pada siklus II disajikan pada Tabel 8

Tabel 8. Analisis Tugas Siswa Pada Siklus II

\begin{tabular}{|c|c|c|c|c|}
\hline Siklus II & Pertemuan & Nilai Tugas Rata-rata & $\begin{array}{l}\text { Rata-Rata Nilai } \\
\text { Tugas Siklus II }\end{array}$ & Kategori \\
\hline & $\mathrm{I}$ & 77,4 & 84,9 & Baik \\
\hline & II & 92,3 & & \\
\hline
\end{tabular}

Berdasarkan data pada tabel 8, dimana rata-rata nilai tugas siswa pada Siklus II ialah sebesar 84,9 termasuk kategori baik. Bila diperhatikan perpertemuan terjadi peningkatan rata-rata nilai tugas siswa dimana pada pertemuan pertama rata-rata nilai tugas siswa sebesar 77,4 , kemudian pertemuan kedua mengalami peningkatan menjadi 92,3.

Kemudian data terkait hasil observasi terhadap kesiapan belajar siswa pada Siklus II disajikan pada Tabel 9 berikut

Tabel 9. Analisis Hasil Observasi Kesiapan Belajar Siswa Pada Siklus II

\begin{tabular}{ccccc}
\hline Siklus II & Pertemuan & $\begin{array}{c}\text { Rata-rata Aktivitas Siswa } \\
(\%)\end{array}$ & $\begin{array}{c}\text { Persentase Total } \\
\text { Siklus II }\end{array}$ & Kategori \\
\cline { 2 - 5 } & I & $61 \%$ & $70 \%$ & TINGGI \\
II & $79 \%$ & & \\
\hline
\end{tabular}

Berdasarkan Tabel 9, dimana hasil observasi belajar siswa pada Siklus II persentase yang diperoleh ialah sebesar 70\% sangat jauh berbeda dengan hasil observasi belajar siswa pada Siklus I. Hasil observasi kesiapan belajar siswa pada Siklus II masuk ke dalam kategori tinggi. Bila diperhatikan perpertemuan terjadi peningkatan rata-rata nilai observasi kesiapan belajar siswa yang sangat signifikan dimana pada pertemuan pertama rata-rata aktivitas hasil observasi kesiapan siswa sebesar $61 \%$, kemudian pertemuan kedua terjadi sedikit peningkatan aktivitas hasil observasi kesiapan belajar siswa dalam mengikuti pembelajaran yaitu sebesar 79\%. Secara keseluruhan hasil observasi kesiapan belajar siswa telah berada pada kategori tinggi dengan rata-rata persentase sebesar $70 \%$.

Hasil belajar siswa kelas XI IPA1 SMA Laboratorium Undiksha Singaraja setelah diterapkannya metode pemberian tugas pra-pembelajaran berbanding lurus dengan kesiapan belajar siswa karena meningkatnya kesiapan belajar siswa maka akan diikuti dengan peningkatan hasil belajar. Hasil belajar siswa SMA Laboratorium Undiksha Singaraja pada KD 3.2 materi teori tumbukan dan persamaan laju reaksi pada Siklus II diperoleh data sesuai Tabel 10 berikut. 
Tabel 10. Hasil Belajar Siswa Pada Siklus II

\begin{tabular}{llll}
\hline Rentang Nilai & Kategori Nilai & Jumlah siswa & Persentase \\
\hline $90-100$ & Sangat Baik & 13 & $50 \%$ \\
$80-89$ & Baik & 8 & $31 \%$ \\
$65-79$ & Cukup Baik & 5 & $19 \%$ \\
$55-64$ & Kurang Baik & 0 & $0 \%$ \\
$0-54$ & Sangat Kurang Baik & 0 & $0 \%$ \\
\hline
\end{tabular}

Berdasarkan data pada tabel 10 menunjukkan sebaran yang berbeda dari hasil belajar siswa pada Siklus I, dimana pada Siklus II data yang diperoleh yaitu 13 orang siswa mendapat nilai pada rentangan 90 - 100 dikategorikan sangat baik atau sebesar 50\% dari total keseluruhan siswa yang berjumlah 26 orang, 8 orang siswa mendapat nilai pada rentangan 80 - 89 dikategorikan baik atau sebesar 31\% dari total keseluruhan siswa yang berjumlah 26 orang, 5 orang siswa mendapat nilai pada rentangan 65 - 79 cukup baik atau sebesar 19\% dari total keseluruhan siswa yang berjumlah 26 orang, dan tidak ada siswa yang memperoleh nilai antara rentang 55 - 64 dan rentang nilai 0 - 54. Berbeda dengan Siklus I masih ada siswa yang memperoleh nilai dalam kategori sangat kurang baik. Rata-rata hasil belajar siswa pada Siklus II adalah 88,8 dengan dikategorikan baik.

Dilihat dari nilai kriteria ketuntasan minimal yang telah ditetapkan oleh guru mata pelajaran Kimia SMA Laboratorium Undiksha Singaraja untuk kelas XI sebesar 78 dalam skala 100 dapat diketahui berdasarkan hasil belajar siswa pada Siklus II jumlah siswa yang tuntas dan siswa yang belum tuntas dalam pembelajaran Kimia materi Teori tumbukan dan Persamaan Laju. Sebaran frekuensi ketuntasan belajar siswa pada Siklus II dapat dilihat pada tabel 11 berikut.

Tabel 11. Frekuensi Ketuntasan Belajar Siswa Pada Siklus II

\begin{tabular}{cccc}
\hline Rentang Nilai & Keterangan & Jumlah siswa & Prosentase \\
\hline$\geq 78$ & Tuntas & 22 & $84.6 \%$ \\
$\leq 78$ & Belum Tuntas & 4 & $15.4 \%$ \\
\hline
\end{tabular}

Berdasarkan data pada Tabel 11, jumlah siswa tuntas atau hasil belajar siswa diatas nilai kriteria ketuntasan minimal (KKM) 83 berjumlah 22 orang dari 26 orang siswa atau 84,6\%. Sedangkan siswa yang belum tuntas atau hasil belajarnya di bawah nilai kriteria ketuntasan minimal (KKM) 83 berjumlah 4 orang dari 26 siswa atau 15,4\%. Dapat dikatakan hasil belajar siswa pada Siklus II sangat tinggi dibuktikan dengan besarnya perbedaan antara persentase siswa yang belum tuntas dibandingkan dengan persentase siswa yang telah tuntas.

\section{Pembahasan}

Berdasarkan hasil penelitian yang telah diuraikan di atas, diperoleh 2 temuan yang bermakna. Adapun temuan bermakna tersebut yaitu (1) Pemberian tugas pra-pembelajaran mampu meningkatkan kesiapan belajar siswa kelas XI IPA 1 SMA Laboratorium Undiksha Singaraja (2) Pemberian tugas prapembelajaran mampu meningkatkan hasil belajar siswa kelas XI IPA 1 SMA Laboratorium Undiksha Singaraja. Penelitian ini sudah sejalan dengan beberapa penelitian yang telah dilakukan. Penelitian melaporkan bahwa metode pemberian tugas memberikan pengaruh yang signifikan terhadap hasil belajar siswa pada mata pelajaran Sosiologi (Novariyanti, 2017). Penelitian juga menyatakan bahwa terjadi peningkatan hasil belajar siswa yang signifikan pada mata pelajaran Matematika dengan penerapan metode pemberian tugas (Arifin, 2018).

Pemberian tugas pra-pembelajaran khususnya pada materi Laju Reaksi, di kelas XI IPA1 SMA Laboratorium Undiksha Singaraja membuat siswa lebih siap mengikuti pembelajaran. Siswa diberikan tugas berupa membuat rangkuman tentang materi yang akan dipelajari sehingga sebelumnya siswa sudah membaca di rumah materi yang akan dibahas di kelas, sehingga siswa memiliki pengetahuan awal dan siswa lebih siap menerima materi pembelajaran. Pengetahuan awal merupakan suatu hal yang paling penting sebagai pemicu untuk menciptakan pemahaman yang lebih baik. Jika siswa tidak memiliki pengetahuan awal, maka dalam pembelajaran di kelas siswa akan kebingungan untuk mengartikan istilah istilah baru di dalam materi pembelajaran.

Peningkatan kesiapan belajar siswa tentunya tidak terlepas dari ketepatan metode atau strategi yang digunakan oleh guru hal ini didasarkan atas hasil observasi saat kegiatan pembelajaran berlangsung. 
Saat pengamatan yang dilaksanakan pada refleksi awal siswa jarang sekali merespon pertanyaan atau memberikan tanggapan sehingga kegiatan pembelajaran menjadi pasif. Namun setelah penerapan Siklus I kegiatan pembelajaran sudah mengalami perubahan, telah terbentuknya interaksi dalam proses pembelajaran baik interaksi siswa dengan guru, maupun siswa dengan siswa. Siswa mulai aktif merespon pertanyaan guru tetapi belum keseluruhan siswa mampu merespon pertanyaan tersebut.

Setelah pelaksanaan Siklus II telah terjadi perubahan yang sangat signifikan, sekitar 70\% siswa nampak aktif dalam merespon atau memberikan tanggapan terhadap pertanyaan dari guru dan jawaban dari siswa lain. Selain itu siswa mulai menggunakan sumber belajar selain LKS yang diberikan guru ataupun LKS dari MGMP. Dari pelaksanaan Siklus I sampai akhir Siklus II telah terjadi peningkatan kesiapan belajar siswa berdasarkan observasi pada kegiatan pembelajaran, hal ini dibuktikan dengan perolehan nilai tugas dan nilai observasi kesiapan belajar siswa. Pada Siklus I nilai rata-rata tugas yang diperoleh siswa secara klasikal adalah 65,13 dengan kategori cukup baik. Sedangkan nilai rata-rata kesiapan belajar yang diperoleh siswa adalah 44,6\% atau kesiapan belajar siswa berdasarkan observasi masih dikategorikan sedang. Pada Siklus II nilai rata-rata tugas yang diperoleh siswa adalah 84,86 dengan kategori baik. Sedangkan nilai rata-rata yang diperoleh siswa adalah 70\% atau kesiapan belajar siswa berdasarkan observasi sudah berkategori sangat tinggi. Dapat dilihat bahwa dengan meningkatnya nilai rata-rata tugas siswa maka kesiapan belajar siswa juga meningkat. Seperti yang dinyatakan oleh Erna (2008) tugas pra-pembelajaran dapat meningkatkan aktifitas siswa dalam proses pembelajaran.

Terjadinya peningkatan yang signifikan dari pelaksanaan Siklus I ke Siklus II dikarenakan beberapa faktor yaitu 1) siswa telah mempunyai pengalaman dalam membuat rangkuman materi pembelajaran yang akan dipelajari, 2) siswa memiliki pengetahuan awal tentang materi yang akan dipelajari melalui pembuatan tugas pra-pembelajaran, 3) penyampaian hasil belajar siswa baik secara individual maupun kelompok, menimbulkan rasa jengah, untuk berkompetisi dalam memperoleh hasil belajar yang lebih baik, dan 4) pemanfaatan sumber belajar yang lebih variatif.

Seorang siswa dikatakan belajar apabila terjadi suatu perubahan dalam diri siswa yang disebabkan oleh pengalaman yang dapat mempengaruhi tingkah laku siswa (Muhibbinsyah, 2005). Pemberian tugas pra-pembelajaran telah menimbulkan perubahan dalam diri siswa. Siswa menjadi lebih siap dalam mengikuti pembelajaran karena siswa sudah memiliki pengetahuan awal. Pengetahuan awal sangat penting dalam proses pembelajaran, karena sebelumnya siswa telah mempelajari materi yang akan diberikan. Siswa telah memiliki konsep-konsep dasar yang dapat membantu suasana belajar menjadi lancar dan sistematis.

Pemberian tugas pra-pembelajaran membuat siswa memperoleh pengetahuan tidak hanya dari guru melainkan juga diperoleh dari teman dan berbagai sumber belajar yang digunakan. Siswa dapat memperoleh pengetahuan dari teman dikarenakan siswa dapat mendiskusikan tugas tersebut di rumah bersama temannya selain itu dalam pembelajaran, guru selalu melaksanakan pembelajaran dalam kelompok-kelompok belajar yang heterogen, sehingga akan terjadi interaksi yang positif antara siswa, dimana siswa dapat sharing mengenai pengetahuan awal yang didapat ketika membuat tugas tersebut sehingga daya ingat siswa terhadap materi tersebut lebih lama.

Hal ini terlihat dari hasil tes akhir pelaksanaan Siklus, hasil tes ahkir pelaksanaan Siklus merupakan titik acuan pengukuran hasil belajar siswa. Hasil belajar siswa memberikan gambaran positif dimana pada setiap Siklus terjadi peningkatan hasil belajar hal ini membuktikan bahwa pemberian tugas pra-pembelajaran membuat siswa lebih siap untuk belajar karena siswa sudah memiliki pengetahuan awal sehingga materi pembelajaran akan lebih lama diingat oleh siswa. Hasil belajar siswa kelas XI IPA1 SMA Laboratorium Undiksha Singaraja pada Siklus I jumlah siswa yang hasil belajarnya dalam kategori sangat baik tidak ada sedangkan pada Siklus II jumlah siswa yang berkategori sangat baik ialah berjumlah 13 orang atau 50\%. Siswa yang hasil belajarnya berkategori baik pada Siklus I sebanyak 7 orang atau $27 \%$ dan pada Siklus II sebanyak 8 orang atau 31\%. Siswa yang hasil belajarnya berkategori cukup baik pada siklus I sebanyak 14 orang atau 54\% dan pada Siklus II sebanyak 5 orang atau 19\%. Pada Siklus I siswa dengan hasil belajar sangat kurang baik masih ditemukan yaitu sebanyak 5 orang atau 19\% sedangkan pada pelaksanaan Siklus II tidak ada siswa yang hasil belajarnya berkategori kurang baik dan sangat kurang baik. Berdasarkan peningkatan nilai yang dicapai siswa, maka dapat dikatakan bahwa pemberian tugas pra-pembelajaran merupakan alternatif yang tepat dalam meningkatkan kesiapan dan hasil belajar siswa.

\section{Simpulan dan saran}

Berdasarkan uraian pembahasan di atas dapat disimpulkan beberapa hal sebagai berikut:

1. Penerapan metode pemberian tugas pra-pembelajaran dapat meningkatkan kesiapan belajar Kimia pada siswa kelas XI IPA1 SMA Laboratorium Undiksha Singaraja. Hal ini dapat dilihat dari nilai tugas siswa dan persentase nilai observasi kesiapan belajar siswa. Adapun pada Siklus I nilai rata-rata 
tugas yang diperoleh siswa secara klasikal adalah 65,13 masuk ke dalam kategori cukup baik dan nilai rata-rata kesiapan belajar yang diperoleh siswa adalah 44,6\% masuk ke dalam kategori sedang. Pada Siklus II nilai rata-rata tugas yang diperoleh siswa adalah 84,86 masuk ke dalam kategori baik. Dan nilai rata-rata yang diperoleh siswa adalah 70\% masuk ke dalam kategori sangat tinggi. Jadi dapat disimpulkan bahwa terjadi peningkatan kesiapan belajar siswa seiring dengan meningkatnya nilai tugas.

2. Penerapan metode pemberian tugas pra-pembelajaran dapat meningkatkan aktivitas siswa kelas XI IPA1 SMA Laboratorium Undiksha Singaraja. Hal ini dapat dilihat dari hasil observasi. Siswa yang awalnya enggan untuk merespon pertanyaan guru menjadi aktif dan antusias karena memiliki kesiapan belajar yang baik. Seiring dengan meningkatnya kesiapan belajar siswa, aktivitas siswa dalam pembelajaran juga meningkat.

3. Penerapan metode pemberian tugas pra-pembelajaran dapat meningkatkan hasil belajar Kimia pada siswa kelas XI IPA1 SMA Laboratorium Undiksha Singaraja. Hal ini dapat dilihat dari persentase sebaran hasil belajar siswa dimana pada Siklus I sebesar $27 \%$ berkategori baik, 54\% berkategori cukup baik, dan 19\% berkategori sangat kurang baik. Sedangkan pada Siklus II terjadi perubahan yang signifikan dimana 50\% siswa berkategori sangat baik, 31\% berkategori baik dan hanya 19\% yang berkategori cukup baik. Dilihat dari banyaknya siswa yang mendapatkan hasil belajar diatas KKM pada Siklus I siswa yang tuntas sebesar 38,5\% dan pada Siklus II siswa yang tuntas sebanyak $84,6 \%$. Jadi dapat disimpulkan bahwa terjadi peningkatan hasil belajar yang signifikan dari Siklus I ke Siklus II.

Saran yang bisa diberikan terkait penelitian ini adalah guru mata pelajaran Kimia diharapkan mencoba penerapan metode pemberian tugas pra-pembelajaran dalam pembelajaran Laju Reaksi maupun dikembangkan pada materi Kimia yang lain pada tingkat kelas yang berbeda. Hal ini perlu dilakukan karena pemberian tugas pra-pembelajaran dapat meningkatkan kesiapan dan hasil belajar siswa karena dengan metode ini guru dapat memberikan suasana yang baru dalam belajar dan siswa lebih dituntut untuk mencari sumber belajar lain. Selain itu, guru perlu lebih kreatif dan inovatif dalam merancang tugas pra-pembelajaran yang diberikan kepada siswa sehingga siswa lebih tertantang untuk mengerjakannya.

\section{Daftar Rujukan}

Arifin, R. (2018). Pengaruh Metode Resitasi Terhadap Hasil Belajar Matematika Ditinjau Dari Motivasi Berprestasi Siswa Kelas Vii Madrasah Tsanawiyah Negeri Gowa Kabupaten Gowa. UIN Alaudin Makassar.

Depdiknas. (2006). Kurikulum Tingkat Satuan Pendidikan Sekolah Menengah Atas. Jakarta: Depdiknas.

Erna. (2008). Strategi Pemberian Tugas Pra-Pembelajaran dan Embedded Test untuk Meningkatkan Kualitas Pembelajaran pada Mata Kuliah Kimia Fisika I. Pekanbaru: Universitas Riau.

Jayadiningrat, M. G., Tika, I. N., \& Yuliani, N. P. (2017). Meningkatkan Kesiapan Dan Hasil Belajar Siswa Pada Pembelajaran Kimia Dengan Pemberian Kuis Di Awal Pembelajaran. Jurnal Pendidikan Kimia Indonesia, 1(1), 7-12.

Kunandar. (2016). Langkah Mudah Penelitian Tindakan Kelas. Depok: Raja Grafindo Persada.

Muhibbinsyah. (2005). Psikologi Belajar. Jakarta: Raja Grafindo Persada.

Novariyanti, F. (2017). Penerapan Metode Resitasi Terhadap Hasil Belajar Dalam Pembelajaran Sosiologi Di Kelas XI IPS 1 Sma Islamiyah Pontianak. Universitas Tanjungpura.

Nurkancana, \& Sunartana. (1992). Evaluasi Pendidikan. Surabaya: Usaha Nasional.

Roestiyah. (2008). Strategi Belajar Mengajar. Jakarta: PT. Rineka Cipta.

Slameto. (2003). Belajar dan Faktor-Faktor yang Mempengaruhinya. Jakarta: PT. Rineka Cipta.

Sudjana. (2010). Penilaian Hasil dan Proses Belajar Mengajar. Bandung: PT. Remaja Rosdakarya. 
Sugiyono. (2010). Metode Penelitian Pendidikan Pendekatan Kuantitatif, Kualitatif dan R\&D. Bandung: Penerbit Alfabeta.

Wijaya, I. K. W. B. (2014). Pengaruh Model Pembelajaran Generatif Terhadap Keterampilan Berpikir Kreatif dan Keterampilan Proses Sains Siswa. Jurnal Pendidikan Dan Pembelajaran IPA, 4(1).

Wijaya, I. K. W. B., Kirna, I. M., \& Suardana, I. N. (2012). Model Demonstrasi Interaktif Berbantuan Multimedia Dan Hasil Belajar Ipa Aspek Kimia Siswa Smp. Jurnal Pendidikan Dan Pengajaran, 45(1). 